(C)2019, Elsevier. This manuscript version is made available under the CC-BY-NC-ND 4.0 license http:// creativecommons.org/licenses/by-nc-nd/4.0/

\title{
1 Phosphorus-cycle disturbances during the Late Devonian anoxic events
}

2

3 L.M.E. Percival ${ }^{1 * \pm}$, D.P.G. Bond ${ }^{2}$, M. Rakociński ${ }^{3}$, L. Marynowski, ${ }^{3}$ A.v.S. Hood ${ }^{4}$, T. Adatte $^{1}$, J.E.

$4 \quad$ Spangenberg ${ }^{5}$, K.B. Föllmi ${ }^{1}$

5

6

7

8

9

10

11

12

13

14

15

16

17

18

19

20

21

1: Institute of Earth Sciences, University of Lausanne, Géopolis, 1015 Lausanne, Switzerland

2: Department of Geography, Geology and Environment, University of Hull, Cottingham Road, Hull, HU6 7RX, $U K$

3: Faculty of Earth Sciences, University of Silesia, Będzińska 60, 41-200 Sosnowiec, Poland

4: School of Earth Sciences, University of Melbourne, Victoria 3010, Australia

5: Institute of Earth Surface Dynamics, University of Lausanne, Géopolis, 1015 Lausanne, Switzerland

士: Current address - Analytical, Environmental and Geochemistry Group, Vrije Universiteit Brussel, 1050

Brussels, Belgium

*Corresponding author e-mail - lawrence.percival11@gmail.com

\section{ABSTRACT}

The Late Devonian was marked by repeated faunal crises and episodes of geographically widespread marine anoxia, and featured one of the 'Big Five' mass extinctions of the Phanerozoic Aeon during the Frasnian-Famennian transition. However, the processes responsible for causing the numerous anoxic events remain unclear. This study highlights the occurrence of disturbances to the phosphorus cycle during several Late Devonian crises by investigating sedimentary concentrations of the element $\left(P_{\text {tot }}\right)$ as a tracer of nutrient influx, as well as its ratio with total organic carbon (TOC) to infer the recycling of the element from marine sediments. Increased TOC/P $\mathbf{P}_{\text {tot }}$ ratios in the Frasnian-Famennian Lower and Upper Kellwasser horizons and upper Famennian Annulata and Hangenberg levels suggest that such nutrient recycling occurred across extensive areas of the marine shelf in Laurentia and both Rheic Ocean margins at those times, helping to sustain reducing conditions in those 
environments. Elevated $\mathbf{P}_{\text {tot }}$ values in the Upper Kellwasser, Annulata, and Hangenberg levels are consistent with an enhanced nutrient influx as the initial trigger for the anoxia. Correlation of phosphorus trends with other geochemical indicators of weathering/detrital influx (osmiumisotope, silicon/aluminum, and titanium/aluminum ratios) support a scenario in which terrestrial runoff provided these nutrients both to marine shelves and the oceanic inventory. Upwelling of oceanic deep-water bodies may have then brought the phosphorus to areas that had not featured major direct inputs of terrigenous material. The exception is the Lower Kellwasser Event, during which there was no increase in phosphorus delivery to marine areas and no evidence for terrestrial influx at the studied sections, invoking a different mechanism for the development of water-column anoxia. Clearly, the Late Devonian marine realm was unusually susceptible to becoming anoxic through various possible triggers, including nutrient influx from land and/or deep-water upwelling, and the recycling of phosphorus from newly deposited sediments.

\section{KEYWORDS} Phosphorus; Late Devonian; marine anoxia; nutrient recycling; Frasnian-Famennian extinction

\section{Introduction}

Numerous episodes of widespread marine anoxia occurred during the Late Devonian ( 383359 Ma; palaeogeography in Figure 1), and are marked in the geological record by the appearance of black shale horizons in Europe and elsewhere (reviewed in Bond and Grasby, 2017; see also: Walliser, 1984, 1996; Joachimski and Buggisch, 1993; Bond and Zatoń, 2003; Bond et al., 2004; Kaiser et al., 2006). The best known of these black shales appear just below and at the Frasnian- 
Lower (LKW) and Upper (UKW) Kellwasser events that culminated in one of the 'Big Five' mass extinctions of the Phanerozoic Aeon (e.g., Raup and Sepkoski, 1982; McGhee, 1996; Racki, 2005;

Bond and Grasby, 2017). Other examples include the upper Famennian Annulata Shale (e.g., Walliser, 1996; Sandberg et al., 2002; Korn, 2010), and the Hangenberg Shale just below the Famennian-Tournasian (Devonian-Carboniferous) boundary that also marks a major biotic crisis (e.g., Walliser, 1996; Caplan and Bustin, 1999; see also review by Kaiser et al., 2016).

62

The anoxic facies exemplified by these black shales also record abundant geochemical and petrographic evidence for depleted water-column oxygen levels, in the form of enrichments in redoxsensitive trace elements, organic-biomarker compositions, pyrite framboid size populations, and perturbations to elemental isotope compositions (e.g., Joachimski and Buggisch, 1993; Joachimski et al., 2001; Bond and Zatoń, 2003; Bond et al., 2004; Racka et al., 2010; Marynowski et al., 2011, 2012; Song et al., 2017; White et al., 2018). Globally documented positive excursions in sedimentary carbon-isotope $\left(\delta^{13} \mathrm{C}\right)$ values of up to $4 \%$ also highlight that these events were associated with significant perturbations to the global carbon cycle (e.g., Joachimski and Buggisch, 1993; Joachimski et al., 2002; Stephens and Sumner, 2003; Chen et al., 2005; De Vleeschouwer et al., 2017). The association of these events with major biospheric crises might suggest that marine anoxia and euxinia had a profound, and possibly cumulative, effect on Devonian ecosystems (e.g., Buggisch, 1991; Bond et al., 2004). However, in some locations water-column deoxygenation is recorded as being either less severe (i.e., suboxic-dysoxic) or absent through the numerous Late Devonian events, suggesting that marine anoxia was certainly not truly global in extent, and was often intermittent, during those crises (e.g., Bond et al., 2004; Pujol et al., 2006; Marynowski et al., 2012; White et al., 2018). Consequently, abrupt climate cooling has also been proposed as an additional/alternative cause of faunal extinctions during the Kellwasser and Hangenberg crises (e.g., Copper, 1986; Streel et al., 2000; Joachimski and Buggisch, 2002; Kaiser et al., 2016; Song et al., 2017). Nonetheless, regions featuring marine anoxia clearly expanded geographically during the Late Devonian crises, and in this regard these episodes bear a superficial resemblance to the Mesozoic oceanic anoxic events (OAEs), which have been linked with warmer global climates, marine stagnation and/or stratification, 
84 weathering and nutrient runoff, and recycling of nutrients from sediments (see Jenkyns, 2010).

85 However, whilst the Mesozoic OAEs are widely accepted to have been triggered by abrupt climate

86 warming during hyperthermal events, the absence of evidence for similar temperature increases

87 during the numerous Devonian anoxic episodes means that the ultimate trigger of those environmental

88 perturbations remains unknown.

89

To date, alternative hypotheses for what caused the Late Devonian anoxic events have chiefly revolved around triggering oxygen depletion in the water column via an abrupt influx of nutrients to marine settings, resulting in enhanced levels of primary productivity and subsequent eutrophication (Wilder, 1994; Algeo and Scheckler, 1998; Averbuch et al., 2005). One potential source of these nutrients is from major upwelling of deep-water masses (e.g., Copper, 1986, 1998; Pujol et al., 2006). Alternatively, it has been proposed that an increase in continental weathering rates and associated runoff of terrigenous nutrients stimulated the enhanced primary productivity and subsequent marine anoxia (e.g., Wilder, 1994; Algeo and Scheckler, 1998; Averbuch et al., 2005). Increased terrestrial runoff associated with enhanced continental weathering during the Devonian crises has been documented by a number of proxies (e.g., strontium-isotopes, Chen et al., 2005; osmium-isotopes, Percival et al., 2019; silicon/aluminum (Si/Al), titanium/aluminium (Ti/Al), and zirconium/rubidium (Zr/Rb) ratios, Racki et al., 2002; Pujol et al., 2006; Riquier et al., 2006; Weiner et al., 2017; Paschall et al., 2019), with evidence of soil erosion and wildfires from organic-geochemistry studies further highlighting the contribution of terrestrial matter to the marine realm (Marynowski et al., 2012; Kaiho et al., 2013; Rimmer et al., 2015). Here, the distribution of nutrients in marine shelf basins during Late Devonian anoxic events, as well as their potential source, is further investigated, using phosphorus as a tracer of nutrient influx and recycling at a number of new records of Upper Devonian strata with a wide palaeogeographical coverage.

\subsection{The marine phosphorus cycle}


112 surface waters typically contain a very low dissolved P content due to the rapid biological uptake of

113 this element (see review by Filippelli, 2008, and references therein). There are no stable gaseous

114 species of phosphorus in the atmosphere, and hydrothermal emissions and weathering of submarine

115 lithologies represent a negligible source of the element to the marine realm. Consequently, continental

116 weathering, and particularly the runoff of phosphorus bound within organic compounds $\left(\mathrm{P}_{\text {org }}\right)$ from

117 soil erosion, provides the major influx of bioavailable $\mathrm{P}$ to the marine environment (Filippelli and

118 Delaney, 1994; Föllmi, 1995). On geologically short timescales, phosphorus within the marine system

119 is also returned to the shelf environment from deeper waters via the localized upwelling of nutrient-

120 rich waters that have high P concentrations (see reviews by Froelich et al., 1982; Föllmi, 1996; Paytan

121 and McLaughlin, 2007; and references therein).

122

123 At the point of initial deposition on the seafloor, the vast majority of the element is bound to 124 organic matter (Delaney, 1998), with a smaller constituent composed of detrital material, iron-bound

125 P, and the bones/teeth/scales of marine organisms such as fish (Froelich et al., 1982; Schenau and De

126 Lange, 2000; Fantasia et al., 2018). Post burial, a large fraction of $\mathrm{P}_{\text {org }}$ can be converted into

127 authigenic P phases such as carbonate-fluorapatite (CFA) and iron-bound P (Berner et al., 1993).

128 Redox conditions can play an important role in these conversions, with formation of authigenic $\mathrm{P}$

129 phases potentially more prevalent in the presence of bioturbation (i.e., more oxygenated settings);

130 furthermore, anoxic conditions may favour the formation of CFA over iron-bound P phases (see

131 overviews of Algeo and Ingall, 2007; Dale et al., 2016). These early-diagentic transformations form a

132 crucial aspect of long term P burial (the so-called 'sink switch'); however, whilst these processes will

133 reduce the amount of $\mathrm{P}_{\text {org }}$ in the sediment, the $\mathrm{P}_{\text {tot }}$ content should remain unchanged, and in most

134 marine settings the amount of detrital P is sufficiently small that the combined authigenic and organic

$135 \mathrm{P}\left(\mathrm{P}_{\text {reactive }}\right.$ ) will be close to the overall $\mathrm{P}_{\text {tot }}$ content (Algeo and Ingall, 2007). Consequently, whilst both

136 the TOC/ $\mathrm{P}_{\text {org }}$ and TOC/ $\mathrm{P}_{\text {tot }}$ values should initially be close to the Redfield ratio of organic matter

137 when $\mathrm{P}_{\text {org }}$ is deposited to sediments in oxic conditions, any subsequent conversion of $\mathrm{P}_{\text {org }}$ to 
authigenic species would elevate this ratio, although the ratio of $\mathrm{TOC} / \mathrm{P}_{\text {tot }}$ will not be affected by this

139 process.

In reducing conditions, interaction of sediments with oxygen-depleted bottom waters can result in liberation of $\mathrm{P}_{\text {org }}$ back into the water column (e.g., Van Cappellen and Ingall, 1994). Thus, in anoxic marine settings, sedimentary $\mathrm{P}$ is recycled very efficiently and can sustain elevated primary productivity in the overlying water column, whilst greatly reducing the efficiency of phosphorus burial (Van Cappellen and Ingall, 1994). This recycling of $\mathrm{P}_{\text {org }}$ will also elevate TOC/ $\mathrm{P}_{\text {org }}$ values, but will additionally raise the $\mathrm{TOC} / \mathrm{P}_{\text {tot }}$ ratio (although potentially to a lesser degree). Studies of the Mesozoic OAEs have highlighted the potential role played by this nutrient recycling in sustaining enhanced primary productivity and anoxic/euxinic conditions in marine shelf environments, where the onset of anoxia likely resulted from eutrophication associated with an external influx of nutrients to those areas (Mort et al., 2007; Kraal et al., 2010; Westermann et al., 2013; Fantasia et al., 2018).

Previous studies of the sedimentary phosphorus contents during the Late Devonian crises have indicated a likely influx of the element to the marine realm during the UKW Event, with a documented increase in total phosphorus content in the sediments at the base of the UKW Horizon in the West Valley Core (Appalachian Basin, New York, USA; Murphy, 2000; Sageman et al., 2003). Additionally, there is an elevated phosphate concentration in rocks from that stratigraphic level at the Boulongour Reservoir section in northwestern Xinjiang (NW China; Carmichael et al., 2014), with stratigraphically higher peaks documented at the F-F boundary itself in the Syv'yu River section in the subpolar Urals (Russia; Yudina et al., 2002), and a number of Polish sections (Racki et al., 2002). Sedimentary phosphate enrichments have also been noted in the Hangenberg shales just below the

161 Devonian-Carboniferous boundary (Carmichael et al., 2016; Paschall et al., 2019). Furthermore, elevated organic carbon/organic phosphorus ratios from a single record (the West Valley Core) have

163 been interpreted as indicating that once an oxygen-depleted water column had developed, recycling of

164 nutrients from newly deposited sediments likely took place in the oxygen-depleted conditions during 165 the LKW and UKW events, at least in that location (Murphy, 2000; Sageman et al., 2003; see also 
Figure 2). Such nutrient recycling would have resulted in sustained high rates of primary productivity

167 and a consequent prolongation of anoxic conditions. However, the occurrence of such nutrient recycling during the Kellwasser crises has not yet been demonstrated elsewhere, and the source of the increased sedimentary phosphate remains unresolved.

\subsection{Study aims}

172

In this study, six new datasets of total $\mathrm{P}$ concentrations $\left(\mathrm{P}_{\text {tot }}\right)$ are presented from records of the

174 Frasnian-Famennian transition (see Figure 1 for geographic locations), spanning both the northwestern (Steinbruch Schmidt, Germany; Kowala, Poland) and southern (Coumiac, France; Erfoud, Morocco) margins of the Rheic Ocean, and the Australian Canning Basin (South Oscar Range; Dingo Gap). The Steinbruch Schmidt, Kowala, and Coumiac samples were further studied for total organic carbon/total phosphorus $\left(\mathrm{TOC} / \mathrm{P}_{\text {tot }}\right)$ ratios. The analyses are supplemented by combined new and previously published information on primary productivity and input of detrital terrigenous material to Steinbruch Schmidt, Kowala, Coumiac, and Erfoud, with the new aluminium data also used to normalise the $\mathrm{P}_{\mathrm{tpt}}$ contents ( $\mathrm{P}_{\text {tot }} / \mathrm{Al}$ ratios) to determine whether changes in phosphorus were lithologically related. These data allow for an increasingly global picture to emerge of phosphorus cycling during the Frasnian-Famennian transition, particularly for recycling of sedimentary phosphorus in anoxic conditions, which has previously been tested in only one area. The results also allow investigation of the variability in interactions between regional disturbances to the $\mathrm{P}$ cycle and global/local environmental perturbations during the Kellwasser crises. Finally, sediments from Kowala spanning the upper Famennian Annulata and Hangenberg shales are investigated for $\mathrm{P}$ content and TOC/P $\mathrm{P}_{\text {tot }}$ ratios, giving insight into whether the relationship between marine anoxia and 
The abandoned quarry "Steinbruch Schmidt” near the town of Bad Wildungen (Hesse,

197 Germany) records the classic expression of the Kellwasser horizons as two distinct units of black carbonates and shales, interbedded with uppermost Frasnian and lowermost Famennian pelagic limestones (Schindler, 1990; Buggisch, 1991). The section also contains a bentonite that has been precisely uranium-lead dated to $372.36 \pm 0.053 \mathrm{Ma}$, helping to constrain the ages of the two Kellwasser crises (Percival et al., 2018). Two positive excursions are documented in bulk carbonate $\delta^{13} \mathrm{C}$, characteristic of records of the Kellwasser events (Joachimski and Buggisch, 1993). These pelagic sediments were deposited on a submarine rise that was part of a large carbonate platform in northeastern Laurentia (also referred to as the southeastern part of Laurussia), indicating an environment distal from the palaeoshoreline (Meischner, 1971; Devleeschouwer et al., 2002). A minimal influx of detrital terrigenous material to this location is further suggested by decreased Ti/Al, Si/Al, and Zr/Rb ratios within the Kellwasser strata (Pujol et al., 2006; Weiner et al., 2017; and supplementary information therein), and potentially supported by a relatively low kaolinite/illite clay composition (Devleeschouwer et al., 2002).

210 Steinbruch Schmidt are interpreted as recording oxygenated marine conditions, and whilst it is accepted that the Kellwasser horizons mark times of a more oxygen-depleted water column, the

214 degree of anoxia remains less clear. $\mathrm{V} / \mathrm{Cr}$ and $\mathrm{Th} / \mathrm{U}$ ratios from the Kellwasser horizons suggest that 215 at least dysoxic conditions developed, but that sustained anoxia/euxinia probably did not (Pujol et al.,

216 2006; Weiner et al., 2017). This conclusion is supported by ostracod fauna within the UKW Level,

217 which also indicate variable degrees of oxygenation and that truly anoxic conditions were no more 218 than intermittent (Casier and Lethiers, 1998). However, some nearby German sections have been 219 interpreted as recording more sustained anoxia during the Kellwasser events (Bond et al., 2004; Pujol et al., 2006; Riquier et al., 2006), and whilst it is possible that redox changes across individual (but 
close) environments were variable during these crises, it cannot be discounted that the

222 palaeoenvironment at Steinbruch Schmidt also featured prolonged anoxia at those times.

The Kowala Quarry (hereafter named Kowala) is an actively worked site near Kielce in Poland, which exposes a relatively expanded Frasnian through to basal Tournasian (lowest Carboniferous) succession from the Chęciny-Zbrza Basin (see Racki et al., 2002; and references therein). This intra-shelf basin was part of a very widespread carbonate platform that extended across more than $500 \mathrm{~km}$ of the northeastern part of Laurentia. The strata largely consist of organic-rich shales and limestones, often cyclically interbedded, allowing for the reconstruction of a cyclostratigraphic timescale for this record (De Vleeschouwer et al., 2013, 2017). This age model is well constrained by excellent conodont biostratigraphy (Szulczewski, 1996). The LKW Horizon is not clearly defined at Kowala. Percival et al. (2019) interpreted a set of laminated organic-rich shales from $12 \mathrm{~m}$ below the F-F boundary that featured both organic and inorganic geochemical indications of oxygen-depleted conditions as the LKW strata, and this interpretation is followed for this study, but there is no evidence of a positive excursion in $\delta^{13} \mathrm{C}$ values in either bulk carbonate or organic material.

In contrast, the UKW Horizon is very well defined at Kowala, with euxinic conditions indicated by the appearance of finely laminated organic-rich micrites and shales, fine grained framboidal pyrite populations, and trace-metal content perturbations (Joachimski et al., 2001; Racki et al., 2002; Bond et al., 2004). A clear positive excursion in $\delta^{13} \mathrm{C}$ is also documented in both organic matter and bulk carbonates in the UKW Horizon (Joachimski et al., 2001; Percival et al. 2019). However, unlike at Steinbruch Schmidt where non-Kellwasser strata record a continuously welloxygenated water column, several studies indicate that redox conditions at Kowala outside of the times of the Kellwasser events were much more variable, alternating from suboxic at times all the way up to intermittent episodes of euxinia (e.g., Bond and Zatoń, 2003; Bond et al., 2004; 
Marynowski et al., 2011). Increased levels of primary productivity and detrital input have also been reported from the UKW Horizon (Racki et al., 2002; Pujol et al., 2006), whilst shifts in reconstructed osmium-isotope compositions towards radiogenic values further support hypotheses that the Kellwasser horizons at Kowala were deposited during times of globally enhanced continental weathering (Percival et al., 2019).

The upper Famennian Annulata and Hangenberg shales are also currently well exposed at Kowala (e.g., Bond and Zatoń, 2003; Racka et al., 2010; Marynowski et al., 2012). Both horizons are marked by the appearance of black, organic-rich, laminated shales, although the Annulata unit also features more carbonaceous layers (Racka et al., 2010; Marynowski et al., 2012). Osmium-isotope data indicate that the Annulata Event coincided with a global-scale increase in continental weathering rates (Percival et al., 2019). However, detrital influx proxies suggest that the Chęciny-Zbrza Basin itself did not experience a major increase in the input of terrigenous material at that time, although there is evidence for locally enhanced primary productivity (Racka et al., 2010). In contrast, terrestrial organic-material that includes compounds indicative of wildfires is present in the Hangenberg shales, indicating that they were deposited relatively proximally to the palaeoshoreline, and supporting a large terrestrial influx to the marine environment during that later event (Marynowski et al., 2012). Trace-metal enrichments, framboidal pyrite size populations, and organic biomarkers have all been investigated for both levels. Photic-zone euxinia was probably prevalent throughout the early and later parts of the Annulata Event, but with a re-oxygenation event taking place mid-event; however, bottom-water conditions were probably more variably oxic-dysoxic during the early stages of the Annulata crisis, before becoming persistently deoxygenated during the later stages (Racka et al., 2010). Photic-zone euxinia appears to have also prevailed in the Chęciny-Zbrza Basin throughout the Hangenberg Event (Marynowski et al., 2012), but it is less clear how bottom-water conditions developed during this crisis (Marynowski et al., 2012, 2017; Derkowski and Marynowski, 2018). 
279 Coumiac documents a well-oxygenated pelagic setting on the southern margin of the Rheic Ocean

280 (Klapper et al., 1993). The strata are dominated by pale micritic carbonates that were deposited in a pelagic environment, which results in a very condensed stratigraphic succession due to the relatively starved influx of sediment. There is little facies evidence for prolonged marine anoxia during either

283 Kellwasser event at that location, apart from a single thin shale layer preserved at the F-F boundary

284 (Bond et al., 2004). TOC content is negligible throughout the section apart from in the boundary layer, where it reaches $0.3 \mathrm{wt} \%$ (this study, Figure 3C). Pyrite framboids are also only known from the F-F boundary, where their size distributions are consistent with the development of dysoxic, but not truly anoxic or euxinic, conditions in the water column (Bond et al., 2004). Dysoxic conditions during the Kellwasser crises are also supported by moderate increases in $\mathrm{V} / \mathrm{Cr}$ ratios at those event levels (Pujol et al., 2006). Although the pelagic setting is suggestive of minimal terrestrial influence on this environment, an increase in detrital influx during the UKW Event might be indicated by enrichments in $\mathrm{Si} / \mathrm{Al}, \mathrm{Ti} / \mathrm{Al}$, and $\mathrm{Zr} / \mathrm{Al}_{2} \mathrm{O}_{3}$ at the $\mathrm{F}-\mathrm{F}$ boundary (Pujol et al., 2006). Despite the condensed nature of this record, the abundance of well-preserved conodonts allows for well constrained biostratigraphy; oxygen-isotope analysis of these fossils has also indicated cooling temperatures during and following the Kellwasser events (Balter et al., 2008).

2.4. Erfoud (Morocco, $31^{\circ} 25^{\prime} 52.7^{\prime \prime} \mathrm{N}, 4^{\circ} 13^{\prime} 29.8^{\prime \prime} \mathrm{W}$ ) carbonate shelf at the northwestern margin of Gondwana, which faced the southeastern part of the Rheic Ocean, (Wendt and Belka, 1991). Sedimentary samples spanning the stratigraphic record of the

302 Kellwasser horizons and F-F boundary were collected near the town of Erfoud. The succession was 303 deposited on a submarine rise between the Rheris and Tafilalt basins, in the eastern part of the Tafilalt 304 Platform; thus, it is considered to have likely been quite distal from the palaeoshoreline. The lithology 
chiefly consists of limestones topped with condensed surfaces, which are rich in benthic, nektonic, and planktonic fauna. The LKW Horizon is marked by the appearance of laminated dark shales largely devoid of marine fossils, overlain by carbonate breccias and tempestites, which is interpreted here as indicating a marine transgression across the LKW Event followed by an abrupt regression in its aftermath. The UKW Horizon also features fossil-depleted laminated dark shales (with some more carbonaceous layers), but it is overlain by limestones that are also relatively impoverished, dominated

311 by planktonic prasinophytes. A number of erosive horizons outcrop above this 'disaster' bed (50 cm 312 above the top of the UKW Horizon) that may indicate another regressive event shortly after the F-F 313 mass extinction. Thus, the record of water-column deoxygenation at Erfoud is superficially similar to

314 settings in Germany, with transgressive black shales clearly marking the two Kellwasser horizons, and evidence for marine regressions following each crisis (see Bond and Wignall, 2008). Detailed biostratigraphy is lacking for the Erfoud section, but the known positions of the F-F boundary and Kellwasser levels (the latter supported by carbon-isotope data from this study) allow the approximate

318 intervals of the Late rhenana, linguiformis, and triangularis zones to be inferred. Although the rocks

319 clearly show that they have been significantly oxidized, featuring both a reddish appearance and a mineralogy depleted in reduced-iron species such as pyrite, the presence of 3-4 wt\% goethite (the product of pyrite oxidation) in the Kellwasser levels suggests that those shales were indeed deposited in an oxygen-depleted water column. However, given the apparent variability in the degrees of anoxia that developed at the individual German records, it is not clear whether Erfoud records merely suboxic-dysoxic conditions during the Kellwasser crises, or if sustained anoxia/euxinia was a feature of this location. In addition to analysis of $\mathrm{P}$ contents in sediments, $\delta^{13} \mathrm{C}$ values of organic matter were investigated in sediments from this site, in order to verify the stratigraphic positions of the Upper and Lower Kellwasser horizons. 
333 Devonian carbonate reef on the Lennard Shelf, at the edge of the Canning Basin. These records

334 document a well-oxygenated environment on the shelf throughout the Late Devonian, with no 335 indication from the preserved facies that marine anoxia developed in this area during either of the 336 Kellwasser events (Playford, 1980). The section itself was deposited in an open marine environment on the fore-reef slope, with the lithology dominated by platform derived mega-breccias and limestone grainflows in the upper Frasnian strata, overlain by fine-grained limestones above the LKW Horizon (Hillbun et al., 2015). This facies change is consistent with a rise in sea-level during marine transgressions at the onset of both of the Kellwasser crises (Hillbun et al., 2015; Playton et al., 2016). Evidence of deep-water stromatolites observed in strata crossing the UKW Horizon and F-F boundary might support a transgression at that time (George, 1999). In the absence of organic-rich shales or any other evidence for sustained anoxia (such as trace-metal enrichments or organic biomarkers), the stratigraphic position of the Kellwasser horizons has been determined on the basis of two positive $\delta^{13} \mathrm{C}$ excursions in bulk carbonate just below the F-F boundary (Hillbun et al., 2015; Playton et al., 2016). Although marine anoxia is not indicated by the appearance of organic-rich shales, uranium/thorium and vanadium/chromium ratios indicate the possibility of at least dysoxic conditions at the South Oscar Range during those crises (Hillbun et al., 2015). west of the South Oscar Range transect. Upper Frasnian strata record an open-marine embayment within a fore-reef marginal slope environment, lithologically consisting of mega breccias and grainflows (George et al., 1997; Stephens and Sumner, 2003). The F-F boundary has been constrained to within $7 \mathrm{~m}$ on the basis of conodont biostratigraphy (George et al., 1997), and is marked by outcropping of the reef breccias, allochthonous blocks and/or bioherms, often overlain by deep-water stromatolites. In contrast, lower Famennian strata are made up of finer grained silty/sandy 
limestones (George et al., 1997; Stephens and Sumner, 2003). This change in lithology is thought to record a change in sea level, likely a rise during a transgressive event in the latest Frasnian, consistent with models from European records (Stephens and Sumner, 2003). As for the South Oscar Range, the Kellwasser horizons can only be defined on the basis of carbon-isotope chemostratigraphy. Two positive excursions in bulk carbonate $\delta^{13} \mathrm{C}$ values within uppermost Frasnian strata have been interpreted as being time-equivalent to those associated with the Kellwasser levels in Europe and North America (Stephens and Sumner, 2003).

\section{Methods} at the University of Lausanne using a UV/Vis Perkin Elmer Spectro-photometer LAMBDA 25 operating at a wavelength of $810 \mathrm{~nm}$, following the methods in Eaton et al. (1995) and Fantasia et al. (2018). $100 \pm 5 \mathrm{mg}$ of homogeneously powdered sample were weighed into a cleaned vial, and the precise mass recorded. $1 \mathrm{~mL}$ of $1 \mathrm{M} \mathrm{Mg}\left(\mathrm{NO}_{3}\right)_{2}$ was added to the powder, and roasted in an oven at $550{ }^{\circ} \mathrm{C}$ for $2.5 \mathrm{hr}$ (following a stepwise temperature increase of $100{ }^{\circ} \mathrm{C}$ for $30 \mathrm{~min}$ and $250{ }^{\circ} \mathrm{C}$ for a further $30 \mathrm{~min}$ before being elevated to $550{ }^{\circ} \mathrm{C}$ ). Once cooled, $10 \mathrm{~mL}$ of $1 \mathrm{~N} \mathrm{HCl}$ were added to each sample, and the glass vials placed on a shaker for $16 \mathrm{hr}$ to liberate the phosphorus from the dried residue. Samples were then filtered $(0.45 \mu \mathrm{m})$ and transferred to HDPE scintillation vials, and refrigerated overnight before analysis. For clay-rich samples that likely had a high $\mathrm{P}_{\text {tot }}$ content, $40 \mu \mathrm{L}$ of the refrigerated $\mathrm{HCl}$-phosphorus solution was added to $3.95 \mathrm{~mL}$ of $0.1 \mathrm{M} \mathrm{HCl}$ in a plastic vial. For all other samples, $300 \mu \mathrm{L}$ of the phosphorus solution was added to $2.75 \mathrm{~mL}$ of Milli-Q water. $100 \mu \mathrm{L}$ of Mixing Reagent (a 2:1 mixture of ammonium molybdate solution and antimony potassium tartate sulphuric acid solution) and $100 \mu \mathrm{L}$ of absorbic acid were added to all samples (Eaton et al., 1995). 
analytical uncertainty of less than $\pm 5 \%$. A procedural blank and six $\mathrm{PO}_{4}{ }^{3-} \cdot \mathrm{HCl}$ standard solutions (1, $2.5,5,10,15,20 \mu \mathrm{M})$ were used to calibrate the photometric measurements. Lausanne, as described by Behar et al. (2001). The organic-carbon hydrogen index (HI), oxygen index (OI), and temperature of maximum hydrocarbon generation $\left(T_{\max }\right)$ parameters were also measured during these analyses. Aliquots of homogeneous powdered samples were weighed into crucibles, and their precise mass determined. $70 \pm 2 \mathrm{mg}$ were weighed for very carbonate rich samples, with $60 \pm 2 \mathrm{mg}$ weighed for less calcareous powders, and $50 \pm 2 \mathrm{mg}$ for black shales with a likely high organic-matter content. Carbon-isotope values of bulk organic matter $\left(\delta^{13} \mathrm{C}_{\text {org }}\right.$ in \%o vs VPDB) for Erfoud sedimentary rocks were determined on powdered samples that had been decarbonated with $10 \% \mathrm{HCl}$ prior to analysis, using flash combustion on a Carlo Erba 1108 elemental analyser connected to a Thermo Fisher Scientic Delta V isotope ratio mass spectrometer. Other major-element analyses were conducted at the University of Lausanne, following the methods in Percival et al. (2019). New P, Si, Ti, and Al data were generated on a PANalytical PW2400 spectrometer using Xray fluorescence (XRF) analyses of fused lithium tetraborate glass discs, with an analytical uncertainty lower than $\pm 5 \%$ (Fantasia et al., 2018).

\section{Results}

406

\subsection{Total organic carbon content and carbon-isotope data as a marker of the Kellwasser horizons}

411 with, consistent with previously published data (Casier et al., 1999). Notably, the highest TOC values are within the black shale units; the black limestone layers that are also present within the Kellwasser 
414 analyses produced further information regarding the organic matter from within the Kellwasser strata,

415 highlighting very low HI values, but very high OI and $T_{\max }$. Such parameters indicate that the organic

416 carbon currently consists of Type IV Kerogen (see Supplementary Tables and Peters, 1986);

417 consequently, the organic matter at Steinbruch Schmidt is highly mature following oxidation and/or

418 post-burial heating (see also Devleeschouwer et al., 2002) as well as significant surface weathering.

419 Thus, the original TOC content at Steinbruch Schmidt was probably much greater than the quantity

420 measured in the samples. In contrast, the high $\mathrm{HI}$ and relatively low OI and $T_{\max }$ values in black shales

421 at Kowala are indicative of very immature, predominantly marine, organic matter, suggesting that the

422 increased TOC contents recorded at the Kellwasser horizons there reflect original values. A small

423 increase in TOC is also observed in the condensed UKW Horizon at Coumiac $(<0.1 \mathrm{wt} \%$ to $0.3 \mathrm{wt} \%$ :

424 Figure 3C), but even this maximum content is too low to provide meaningful HI, OI, or $T_{\max }$

425 parameters. The oxidized state of the Erfoud sediments means that their current organic content is

426 extremely low, and consequently determination of the above parameters is difficult for that record.

427

New carbon-isotope data from the sediments at Erfoud highlight two positive $\delta^{13} \mathrm{C}_{\text {org }}$

excursions in the black shales that are interpreted as being the Kellwasser horizons at that location

430

(Figure 3D). The stratigraphically higher of the two shifts also continues above the UKW Horizon.

431

Thus, the stratigraphic trends in $\delta^{13} \mathrm{C}$ at Erfoud are consistent with a number of well-known records from Europe and elsewhere (see e.g., Joachimski and Buggisch, 1993; Joachimski et al., 2002).

4.2. Phosphorus concentrations and $P_{\text {tot }} /$ Al ratios analyses shows good comparability between the two methods $\left(r^{2}=0.8110\right.$; see Supplementary Figure 1), and stratigraphic plotting of the data generated by the two methods also shows highly comparable trends, confirming this result (see data in supplementary information). 
443 six studied sites (Figure 3). There is a clear increase (from 129 ppm to $839 \mathrm{ppm}$ ) in $\mathrm{P}_{\text {tot }}$ in LKW

444 sediments at Steinbruch Schmidt (Figure 3A), and whilst there are also peaks up to 0.05 in $\mathrm{P}_{\text {tot }} / \mathrm{Al}$,

445 they do not correspond to the same samples. Rather, the peaks in $\mathrm{P}_{\text {tot }} / \mathrm{Al}$ occur where $\mathrm{P}_{\text {tot }}$ values are

446 near background, but $\mathrm{Al}$ contents are also low; whereas the samples with high $\mathrm{P}_{\text {tot }}$ also feature

447 elevated $\mathrm{Al}$ concentrations, leading to reduced $\mathrm{P}_{\text {tot }} / \mathrm{Al}$. Small increases in $\mathrm{P}_{\text {tot }}$ may also possibly be

448 present at the top of the LKW Horizon at Kowala (from 297 to 644 ppm) and slightly below that level

449 at the South Oscar Range (from 27 to $134 \mathrm{ppm}$ ), although those data are at low resolution (Figures 3B

450 and 3E). Moreover, there is no deviation in $\mathrm{P}_{\text {tot }} / \mathrm{Al}$ values across the $\mathrm{LKW}$ horizon at Kowala

451 compared to either background values or the upper crustal average (Figure 3B). No enrichments in

452 either $\mathrm{P}_{\text {tot }}$ or $\mathrm{P}_{\text {tot }} / \mathrm{Al}$ are recorded in time-equivalent strata at Coumiac (Figure 3C), Erfoud (Figure

453 3D) or Dingo Gap (Figure 3F).

454

$\mathrm{P}_{\text {tot }}$ trends from Upper Kellwasser sediments show greater consistency across the studied sites. There is a clear peak in $\mathrm{P}_{\text {tot }}$ at the base of UKW Horizon at Kowala (to over 3500 ppm; Figure 3B) with additional spikes between the Kellwasser levels, and a similar enrichment in $\mathrm{P}_{\text {tot }}$ at Steinbruch Schmidt (168 ppm to 871 ppm; Figure 3A) beginning in the limestone bed just below the UKW Horizon. In both locations, the samples with elevated $\mathrm{P}_{\text {tot }}$ also feature increased $\mathrm{P}_{\text {tot }} / \mathrm{Al}$ ratios, which in the case of Kowala greatly exceed the average upper crustal value (up to 0.15 at the base of or slightly below the UKW Level). A small increase in $\mathrm{P}_{\text {tot }}$ at the Kowala F-F boundary (to 917 ppm) is also reflected in a large peak in $\mathrm{P}_{\text {tot }} / \mathrm{Al}$ ratio (to 0.167) but again, this peak is exaggerated by a significantly below-average $\mathrm{Al}$ content in that sedimentary layer. An elevation in $\mathrm{P}_{\text {tot }}$ values (to over 2000 ppm) is also recorded within UKW strata at Erfoud, with a single sample also showing a high $\mathrm{P}_{\text {tot }}$ content just below that level (Figure 3D), but only the peak just below the boundary is maintained as a high $\mathrm{P}_{\text {tot }} / \mathrm{Al}$ ratio (of 0.149), suggesting that the $\mathrm{P}_{\text {tot }}$ enrichments within the UKW Horizon at Erfoud may be a product of the lithological change. 
470 (Figure 3C), but the $\mathrm{P}_{\text {tot }} / \mathrm{Al}$ ratios at the boundary and just below are very elevated (up to 0.219 ). This

471

472 result may partly be caused by the very low Al content of the Coumiac sediments (as carbonate-rich pelagic limestones); thus, it is not clear how truly representative of lithological changes these low $\mathrm{Al}$ contents might be. The low-resolution nature of the two Canning datasets means that neither record features $\mathrm{P}_{\text {tot }}$ results from the base of the UKW Horizon (Figures 3E and 3F), although a slight increase across the F-F boundary of the South Oscar Range section might hint at a possible P enrichment across UKW strata at that location.

A large increase in $\mathrm{P}_{\text {tot }}$ is also observed at the base of the Annulata (Figure 4B) and Hangenberg (Figure 4A) horizons at Kowala (from 282 ppm to 2270 ppm, and 285 ppm to 825 ppm, respectively). In the case of the Annulata, $\mathrm{P}_{\text {tot }}$ remains elevated throughout this unit before a second peak at the top of the level, whereas $\mathrm{P}_{\text {tot }}$ returns to background values or less above the base of the Hangenberg shale. Trends in $\mathrm{P}_{\text {tot }} / \mathrm{Al}$ for both stratigraphic levels correlate very well with the $\mathrm{P}_{\text {tot }}$ variations (with enrichments from 0.004 to 0.05 across the Annulata Horizon, and 0.004 to 0.025 for the Hangenberg Level), strongly suggesting that these enrichments in $\mathrm{P}_{\text {tot }}$ are independent of lithological changes.

\subsection{TOC/phosphorus ratios as evidence for nutrient cycling}

The ratio of TOC/ $\mathrm{P}_{\text {org }}$ in modern organic matter was initially proposed to be 106 (Redfield, 1958). Subsequent studies have revised this value to a global average of 140 (e.g., Ho et al., 2003; Martiny et al., 2013) with significant variations between $\sim 50$ and $\sim 2000$ across different geographical regions and species (e.g., Ho et al., 2003; Algeo and Ingall, 2007; Martiny et al., 2013), but seldom exceeding 115 in oxic marine sediments (Dale et al., 2016). The value of 115 is assumed here to have been the same during the Devonian. Whilst this relationship actually applies to TOC/ $\mathrm{P}_{\text {org }}$ rather 
than the TOC/ $\mathrm{P}_{\text {tot }}$ ratios presented here, most phosphorus is deposited through the water column in

497 particulate organic form (Delaney, 1998). Thus, at the time of initial deposition prior to any

498 conversion of $\mathrm{P}_{\text {org }}$ to authigenic phases, TOC/ $\mathrm{P}_{\text {org }}$ should have been roughly equal to TOC/ $\mathrm{P}_{\text {tot }}$, with

499 both ratios theoretically close to Redfield values. Over time, conversion of $\mathrm{P}_{\text {org }}$ to authigenic phases

500 within the sediments will raise TOC/ $\mathrm{P}_{\text {org }}$, but leave TOC/ $\mathrm{P}_{\text {tot }}$ relatively unchanged. Alternatively,

501 liberation of sedimentary $\mathrm{P}_{\text {org }}$ under reducing conditions will inflate both $\mathrm{TOC} / \mathrm{P}_{\text {org }}$ and $\mathrm{TOC} / \mathrm{P}_{\text {tot }}$ (the

502 latter by a lesser degree). Consequently, on the assumption that the content of detrital P is typically

503 very low, it has been proposed that $\mathrm{TOC} / \mathrm{P}_{\text {tot }}$ ratios elevated above the Redfield ratio represent a more

504 reliable indicator of $\mathrm{P}_{\text {org }}$ liberation than TOC/ $\mathrm{P}_{\text {org }}$, unless $\mathrm{P}$ speciation analyses have also been

505 undertaken that can rule out major conversion of organic P to authigenic species as the cause of

506 elevated TOC/P org (Algeo and Ingall, 2007; Kraal et al., 2010).

507

Sedimentary records of all four studied events highlight increases in $\mathrm{TOC} / \mathrm{P}_{\text {tot }}$ ratios. A large increase in TOC/ $\mathrm{P}_{\text {tot }}$ values is recorded within the LKW horizon at Kowala and Steinbruch Schmidt

510 (38 mol/mol to $270 \mathrm{~mol} / \mathrm{mol}$, and $12 \mathrm{~mol} / \mathrm{mol}$ to $222 \mathrm{~mol} / \mathrm{mol}$, respectively; Figures 3A and 3B). In

511 comparison, there is only a slight elevation in $\mathrm{TOC} / \mathrm{P}_{\text {tot }}$ associated with the LKW at Coumiac (5

$512 \mathrm{~mol} / \mathrm{mol}$ to $8 \mathrm{~mol} / \mathrm{mol}$; Figure 3C). Large increases in TOC/P tot ratios are also observed in UKW

513 strata across all of Kowala, Steinbruch Schmidt, and Coumiac, with an increase from $15 \mathrm{~mol} / \mathrm{mol}$ to

$514573 \mathrm{~mol} / \mathrm{mol}$ documented at Kowala (Figure 3B), from $3 \mathrm{~mol} / \mathrm{mol}$ to $111 \mathrm{~mol} / \mathrm{mol}$ at Steinbruch

515 Schmidt (Figure 2A), and from $3 \mathrm{~mol} / \mathrm{mol}$ to $39 \mathrm{~mol} / \mathrm{mol}$ at Coumiac (Figure 3C). Finally, increased

$516 \mathrm{TOC} / \mathrm{P}_{\text {tot }}$ values are recorded within both of the Annulata and Hangenberg levels compared to the

517 sediments below (25 mol/mol to $718 \mathrm{~mol} / \mathrm{mol}$ for the Annulata, and $12 \mathrm{~mol} / \mathrm{mol}$ to $978 \mathrm{~mol} / \mathrm{mol}$ for

518 the Hangenberg; Figure 4).

519

520

521

4.4. Major element proxies for terrestrial influx 
$524 \mathrm{Si} / \mathrm{Al}$ values are more variable within those strata, without showing any indications of enrichment

525 above background Frasnian levels (Figure 5A). There is no deviation from background in either $\mathrm{Si} / \mathrm{Al}$

526 or Ti/Al across the LKW at Kowala, but a pronounced spike in both proxies is observed at the

527 Frasnian-Famennian boundary, with a possible slight increase in Ti/Al at the base of the UKW

528 Horizon (Figure 5B). The Si/Al and Ti/Al data at Coumiac are at a low resolution, but appear to

529 increase marginally just below the Frasnian-Famennian boundary and interpreted UKW Level

530 (Figure 5C). However, it should be noted that $\mathrm{Al}$ contents are very low at Coumiac, and consequently,

531 the trends in these ratios should be interpreted with caution. Similarly to Steinbruch Schmidt, there is

532 no clear evidence for increased $\mathrm{Si} / \mathrm{Al}$ or Ti/Al in either Kellwasser level recorded at Erfoud (Figure

533 5D). These results are generally very comparable with those of Pujol et al. (2006), and the Steinbruch

534 Schmidt trends are also similar to the high-resolution data of Weiner et al. (2017; see supplementary

535 information therein). Pujol et al. (2006) recorded more pronounced spikes in Si/Al and Ti/Al in the

536 UKW Horizons of Kowala and Coumiac than are found here, but these discrepancies may be

537 explained by the fact that these Kowala samples were drilled in a markedly different part of the quarry

538 to the samples used by Pujol et al. (2006), and condensed nature of that record and low-resolution of

539 both datasets at Coumiac.

540

541 A single data-point peak is noted in $\mathrm{Si} / \mathrm{Al}$ in the lower part of the Hangenberg Shale at

542 Kowala; by contrast, Ti/Al values fall across that level (Figure 6A). There are no clear deviations in

543 either $\mathrm{Si} / \mathrm{Al}$ or Ti/Al at the Annulata Level in Kowala (Figure 6B), consistent with the results of

544 Racka et al. (2010).

545

546

5. Discussion 
552 phosphorus has been lost from the sediments following deposition. In the modern, organic P is largely

553 recycled from sediments to the water column in reducing conditions (Van Cappellen and Ingall,

554 1994), and this phenomenon has also been inferred as operating during the Mesozoic OAEs (e.g.,

555 Mort et al., 2007; Westermann et al., 2013; Fantasia et al., 2018). Alternatively, this change could

556 result from a lower influx of authigenic or detrital P to sediments at Kowala during the Kellwasser

557 crises. However, there is clear evidence for anoxic/euxinic conditions at Kowala during both

558 Kellwasser events (e.g., Joachimski et al., 2001; Bond et al., 2004; Pujol et al., 2006; Percival et al.,

559 2019), consistent with the hypothesis of recycling of sedimentary P to the water column under

560 reducing conditions. In contrast, there is no clear negative correlation between $\mathrm{P}_{\text {tot }}$ or $\mathrm{P}_{\text {tot }} / \mathrm{Al}$ and

$561 \mathrm{TOC} / \mathrm{P}_{\text {tot }}$ that might imply a lower influx of detrital or authigenic P (Figure 3B). Consequently, it is

562 concluded that once oxygen-depleted settings developed at Kowala during the two Kellwasser crises,

563 sedimentary phosphorus recycling became a major feature of the marine environment, consistent with

564 conclusions drawn from the Appalachian Basin record in northeastern North America (Murphy et al.,

565 2000; Sageman et al., 2003). Because phosphorus is often a strongly bio-limiting nutrient, such

566 remobilization would have helped sustain a high level of primary productivity in the water column,

567 aiding the prolongation of marine anoxia/euxinia during the Kellwasser crises.

568

569

The less clear TOC/ $\mathrm{P}_{\text {tot }}$ peaks across the Kellwasser levels at Steinbruch Schmidt, with only one data point from each horizon exceeding 115 (Figure 3A), may indicate that recycling of sedimentary $\mathrm{P}_{\text {org }}$ was less efficient in the dysoxic conditions at that location during the crises (compared to the truly anoxic/euxinic environment at Kowala during those times; Pujol et al., 2006; Weiner et al., 2017). However, it is important to note the highly oxidized nature of the Steinbruch Schimidt sediments and likely reduction of sedimentary TOC content since the time of deposition. Thus, the original TOC/ $\mathrm{P}_{\text {tot }}$ ratios in Kellwasser strata at Steinbruch Schmidt were likely higher and could have clearly exceeded 115, before being reduced following the maturation/weathering of organic carbon in that stratigraphic succession (sedimentary $\mathrm{P}_{\text {org }}$ is comparatively resilient to such processes so would have been less likely to be lost; see Kolowith and Berner, 2002). Consequently, it 
579 is interpreted that some degree of sedimentary $\mathrm{P}_{\text {org }}$ recycling took place at Steinbruch Schmidt during

580 the Kellwasser crises and aided the maintenance of oxygen-depleted conditions at those times.

581 Although, without knowing the original TOC content, it is unclear whether this phosphorus

582 regeneration was truly sustained, or merely intermittent, during the two events. As noted above,

583 significant post-depositional oxidation of the Erfoud sediments hinders accurate determination of

584 TOC contents and TOC/ $\mathrm{P}_{\text {tot }}$ ratios for that record. However, given the comparable appearance of

585 laminated black shales within pale limestone facies at the Moroccan section compared to Steinbruch

586 Schmidt and other German Frasnian-Famennian records, it is assumed that nutrient recycling in a

587 similarly oxygen-depleted water column would also have taken place at Erfoud.

588

The very small TOC/ $\mathrm{P}_{\text {tot }}$ increase at the Coumiac UKW Level might indicate a minor amount of phosphorus recycling in the dysoxic conditions proposed to have occurred at that location during the event (Bond et al., 2004; Pujol et al., 2006), potentially muted by more efficient retention of sedimentary phosphorus as iron-bound P. TOC/ $\mathrm{P}_{\text {tot }}$ trends can also not be reconstructed for the South Oscar Range and Dingo Gap sections, due to the negligible organic-carbon content in sediments from those records. However, in the absence of evidence for anoxic conditions developing in the Canning Basin during the Frasnian-Famennian transition (Hillbun et al., 2015; Tulipani et al., 2015), and given the relatively high-energy environment under which the studied sedimentary records from that region formed, it is assumed that there would not have been significant recycling of nutrients from newly deposited sediments. This conclusion may be supported by the low $\mathrm{P}_{\text {tot }}$ content both within the South Oscar Range and Dingo Gap Frasnian-Famennian strata and other beds, suggesting that there was a minimal influx of the element to that region. associated with the Annulata and Hangenberg shales at Kowala strongly support a role for nutrient

604 recycling in sustaining oxygen-depleted conditions during those environmental perturbations (Figure

605 4), consistent with the findings of Racka et al. (2010). Elevated TOC/ $\mathrm{P}_{\text {tot }}$ ratios have been reported 606 from black shale horizons that mark a number of earlier Devonian climate events, such as the 
607 Givetian-Frasnian Frasnes Event and the early Frasnian Punctata Event (Sageman et al., 2003).

608 Consequently, nutrient recycling associated with reducing conditions in the water column appears to

609 have occurred at some locations during each of the Late Devonian crises, and in certain marine basins

610 (e.g., the Chęciny-Zbrza Basin) were a common feature of all those environmental perturbations.

611

612

613 5.2. Phosphorus fluxes during the Devonian crises

614

615

616

palaeoenvironments investigated in this study. No increase in $\mathrm{P}_{\text {tot }}$ or $\mathrm{P}_{\text {tot }} / \mathrm{Al}$ is documented within

617 LKW strata at Coumiac, Erfoud, or Dingo Gap (Figures 3C, 3D, and 3F). The high $\mathrm{P}_{\text {tot }}$ values do not

618 correlate with peaks in $\mathrm{P}_{\text {tot }} / \mathrm{Al}$ ratios at Steinbruch Schmidt (Figure 3A), indicating that they likely

619 result from the change in lithology from organic-lean carbonates to black, clay-rich, shales. The very

620 small increase in $\mathrm{P}_{\text {tot }}$ observed at the top of the LKW Horizon at Kowala occurs stratigraphically

621 above the geochemical evidence for anoxia and P recycling (Figure 3B; see also supplementary figure 1); therefore, it cannot indicate a nutrient influx responsible for the stimulation of those processes. One data point at the South Oscar Range section suggests a $\mathrm{P}_{\text {tot }}$ increase correlative with the base of the LKW Horizon (Figure 3E), but even if there was an increase in nutrient influx to elevate primary productivity, there is no evidence that marine anoxia developed at that location. In addition to the lack of enriched $\mathrm{P}_{\text {tot }}$ contents, there is no evidence from the detrital proxies of $\mathrm{Ti} / \mathrm{Al}$ or $\mathrm{Si} / \mathrm{Al}$ for an increase in terrigenous material at any of Steinbruch Schmidt, Kowala, Coumiac, or Erfoud during the LKW Event (Figure 5). the LKW Event has been shown by stratigraphic trends in Sr and Os isotopes (Chen et al., 2005;

632 Percival et al., 2019), and there is evidence for increased terrestrial runoff to other marine 633 environments in North America and South China (Whalen et al., 2015). But whilst it is clear that 634 anoxia may have been triggered by the direct runoff of terrestrial nutrients from proximal land masses 
in some marine settings during the LKW Event, this does not appear to be the case for any of the more distal environments studied here. Upwelling or alternative inputs of other bio-limiting nutrients

637 (such as iron) to marine shelf environments may also have stimulated elevated primary productivity and consequent anoxic/euxinic conditions during the LKW Event (see Fung et al., 2000; Hutchins et al., 2002, for modern examples), or anoxic conditions may have arisen in the sites studied here via migration of expanded oxygen-minimum zones during a marine transgression (Bond et al., 2004). However, the absence of conclusive $\mathrm{P}_{\text {tot }}$ enrichments from most studied records is indicative that a perturbation of the phosphorus cycle was not the trigger of anoxia for that crisis.

643 In contrast to the absence of elevated phosphorus contents in LKW strata, a clear increase in $\mathrm{P}_{\text {tot }}$ and $\mathrm{P}_{\text {tot }} / \mathrm{Al}$ is documented at the base of UKW Horizon at Kowala (Figure 3B), Erfoud (Figure 3D), Xinjiang in northwest China (Carmichael et al., 2014), and potentially also in basal UKW strata in the West Valley Core from Appalachian Basin (Sageman et al., 2003; see also Figure 2).

648 Additional peaks in $\mathrm{P}_{\text {tot }} / \mathrm{Al}$ are also recorded in strata between the two Kellwasser horizons at Kowala and correlate with slight increases in $\mathrm{Si} / \mathrm{Al}$ and $\mathrm{Ti} / \mathrm{Al}$ (Figure 5B), potentially indicating fluctuations in background terrigenous P influxes to that environment, although these increases might also reflect changes in burial efficiency of P under variable redox conditions (e.g., Algeo and Ingall, 2007). An increase in $\mathrm{P}_{\text {tot }} / \mathrm{Al}$ is also observed within the UKW Horizon at Coumiac, which was also reported for excess $\mathrm{P}_{2} \mathrm{O}_{5}$ (phosphate/aluminum oxide compared to crustal average) concentrations by Pujol et al. (2006). However, it should be noted that there is no increase in $\mathrm{P}_{\text {tot }}$ content within the UKW Horizon at Coumiac, and the very low $\mathrm{Al}$ concentrations in those samples mean that these $\mathrm{P}_{\text {tot }} / \mathrm{Al}$ tends should potentially be interpreted with caution. The elevated $\mathrm{P}_{\text {tot }}$ contents throughout UKW strata at Steinbruch Schmidt are only partially reproduced by high $\mathrm{P}_{\text {tot }} / \mathrm{Al}$ ratios, suggesting that they are partly the result of the change in lithology, as for the LKW trends (Figure 3A). However, peaks in both $\mathrm{P}_{\text {tot }}$ and $\mathrm{P}_{\text {tot }} / \mathrm{Al}$ near the top of and just below the UKW level might be equivalent to the enrichments recorded elsewhere. These results suggest that there was a major influx of phosphorus to the marine realm at the onset of the UKW Event. The $\mathrm{P}_{\text {tot }}$ peak at Kowala also stratigraphically correlates with a shift in osmium isotopes to very radiogenic values at the base of the UKW Horizon (Figure 5B), 
663 indicating that this phosphorus input coincided with enhanced continental weathering rates, and

664 supporting terrestrial runoff as a source of the nutrient. This conclusion is supported by $\mathrm{Si} / \mathrm{Al}$ and

$665 \mathrm{Ti} / \mathrm{Al}$ evidence for an increased detrital input to marine settings at Kowala, and potentially Coumiac,

666 as well as elsewhere during the UKW Event (Figures 5B and 5C; see also data in Racki et al., 2002;

667 Sageman et al., 2003; Pujol et al., 2006; Whalen et al., 2015). However, the absence of evidence for

668 increased terrigenous input to the UKW palaeoenvironments at either Erfoud or Steinbruch Schmidt

669 (Figures 5A and 5D; see also Pujol et al., 2006; Weiner et al., 2017), or for other German UKW

670 settings (Pujol et al., 2006; Riquier et al., 2006; Weiner et al., 2017), suggests that there was a non-

671 terrestrial nutrient source to some marine areas.

672

673

Whilst a record of elevated $\mathrm{P}_{\text {tot }}$ contents (and $\mathrm{P}_{\text {tot }} / \mathrm{Al}$ ratios; Figure $4 \mathrm{~B}$ ) across the entire

674

stratigraphic interval of the Annulata Horizon at Kowala is consistent with the findings of Racka et al.

675 (2010), this trend is unexpected. Elevated TOC/ $\mathrm{P}_{\text {tot }}$ ratios far in excess of 115 in the Annulata shales

676 are interpreted as marking significant recycling of organic phosphorus from marine sediments at that

677 time, which should have limited burial of the element. It is possible that there was a significant

678 accumulation of detrital/authigenic P deposited in this area during the Annulata Event, as such species

679 would not have been remobilized in the oxygen-depleted settings, allowing for an elevated $\mathrm{P}_{\text {tot }}$

680 content. However, neither this study or previous work suggests a major influx of terrigenous material

681 or terrestrial organic matter to the Kowala palaeoenvironment during the Annulata Event, particularly

682 during the later part of the crisis (Figure 6B; see also Racka et al., 2010), which does not support an

683 enhanced input of detrital P to the area at that time. Alternatively, intermittent episodes of re-

684 oxygenation during the anoxic episode may have allowed for retention of $\mathrm{P}$ alongside recycling

685 during times of more reducing conditions. Such a scenario would still have required an external influx

686 of $\mathrm{P}$ to the local marine environment. As for the UKW level, the elevations in $\mathrm{P}_{\text {tot }}$ and $\mathrm{P}_{\text {tot }} / \mathrm{Al}$

687 correlates with a shift in osmium-isotope values to a more radiogenic composition (Figure 6B; see

688 also Percival et al., 2019), suggesting that even if there was no direct increase in terrestrial runoff to

689 the marine environment at Kowala, globally-enhanced continental weathering could have still

690 delivered nutrients such as phosphorus to the global ocean. This phosphorus could then have been 
recycled via upwelling to locations that had not been affected by a terrestrial influx during the

692 Annulata Event, such as Kowala.

693

694

The documentation of a peak in $\mathrm{P}_{\text {tot }}$ and $\mathrm{P}_{\text {tot }} / \mathrm{Al}$ values (Figure 4A) at the base of the

695

Hangenberg shale at Kowala is consistent with previously published $\mathrm{P}_{2} \mathrm{O}_{5}$ trends from Xinjiang in

696 northwest China and Cat Co 3 in northeast Vietnam (Carmichael et al., 2016; Paschall et al., 2019),

697 indicating that widespread marine anoxia was likely stimulated by enhanced primary productivity following an abrupt increase in the influx of nutrients, at least in those three areas. Carmichael et al.

699 (2016) proposed that the nutrient input at Xinjiang was derived from runoff of terrigenous material.

Documented evidence for nearby wildfires and a high fraction of terrestrial material in organic-matter

701 studies of the Kowala Hangenberg level are indicative of this Polish sequence being deposited close to land (Marynowski et al., 2012), and an increase in Si/Al above background and average upper crustal values supports such an elevation in terrigenous influx, although $\mathrm{Ti} / \mathrm{Al}$ ratios do not show such a change (Figure 6A). Similar observations regarding the influence of the proximal terrestrial realm have been made for Devonian-Carboniferous strata in both the Appalachian and Illinois basins of the western USA (Rimmer et al., 2015; see also Martinez et al., 2019). Consequently, it is likely that the development of anoxic conditions at Kowala during the Hangenberg Event was also triggered by the enhanced input of terrestrial nutrients, as postulated for Xinjiang and the Appalachian and Illinois basins (Rimmer et al., 2015; Carmichael et al., 2016). However, the Cat Co 3 palaeoenvironment lacked proximal land masses, leading Pascahall et al. (2019) to rule out a terrestrial nutrient influx for that location, and Martinez et al. (2019) have also postulated that a terrestrial nutrient influx may have been less important than a marine one in distal-deltaic settings in the area of modern day Cleveland

713 (Ohio, USA). 
It is clear that the development of marine anoxia/euxinia during the Late Devonian events was stimulated by terrestrial runoff in some settings. Even where the direct input of terrigenous material was limited, the influx of continental runoff to the global ocean elsewhere (as evidenced by weathering/detrital proxies) likely increased the oceanic nutrient inventory. Consequently, upwelling of deep waters to marine shelves may have recycled the terrestrial nutrients to areas that did not experience major inputs of terrestrial runoff (as seen off the west coast of Peru today; Burnett, 1977; Burnett et al., 1983 Hutchins et al., 2002), extending the area of oxygen-depleted water bodies. Such a mechanism may explain the increased P contents for the UKW Horizon at Steinbruch Schmidt, the Annulata Shale at Kowala, and the Hangenberg Shale at Cat Co 3, despite no evidence of direct major terrestrial runoff to any of those settings. Marine transgressions associated with both Kellwasser crises and the Annulata Event may also have aided the spread of anoxic water masses at those times (e.g., Sandberg et al., 2002; Bond et al., 2004), and might have been particularly important during the LKW Event, for which there is little evidence of direct phosphorus influx to the marine environment. Further work is needed to determine which of direct terrestrial runoff to marine basins, recycling of those nutrients from deep waters, or spread of oxygen-depleted water masses during sea-level changes were most important on a global scale for each of the Late Devonian crises, and it is likely that all of those processes played some role in initiating the spread of anoxic conditions during those times.

Once anoxic/euxinic conditions had arisen in the water column, recycling of nutrients was likely a key factor in prolonging oxygen-depleted conditions in some marine areas (such as Kowala and the Appalachian Basin) by stimulating sustained high levels of primary productivity. Oxygenisotope records from several sedimentary archives of the two Kellwasser events indicate that both Kellwasser crises were associated with global cooling, although spells of warming might have taken

741 place superimposed upon those lower temperatures (Joachimski and Buggisch, 2002; Balter et al., 2008; Le Houedec et al., 2013; Huang et al., 2018). Moreover, sedimentary evidence for southern-

743 hemisphere ice sheets have been dated to the latest Famennian on the basis of miospore

744 biostratigraphy, suggesting that the Hangenberg Event also took place in a relatively cold global 745 climate (e.g., Caputo et al., 1986; Streel et al., 2000; Kaiser et al., 2016). Cold temperatures might 
have helped enhance continental weathering rates and increase nutrient runoff through elevated erosive processes during glacial expansion and deglaciation (although there is currently no direct evidence for glaciation during the Kellwasser or Annulata crises), but climate cooling should also have encouraged a more oxygenated water column. By contrast, the Mesozoic OAEs are thought to have been associated with hyperthermal events that would have readily promoted oceanic stagnation, further aided by nutrient runoff and recycling associated with warming-driven weathering, all of which there is evidence for during the Mesozoic events (e.g., Mort et al. 2007; Kraal et al., 2010; Fantasia et al., 2018). Consequently, recycling of sedimentary phosphorus in an oxygen-depleted water column to sustain high levels of primary productivity and eutrophication may have been more important for the prolongation of anoxic conditions during the Devonian events than the later Mesozoic ones.

Whatever the precise trigger(s) of each of the individual Late Devonian anoxic events were, the fact that oxygen-depleted water columns developed on numerous occasions during the Frasnian and Famennian stages, likely caused by various mechanisms that may have had different triggers, suggests that the marine realm was particularly susceptible to deoxygenation during that time interval. Several long-term environmental systems experienced major changes throughout Middle-Late Devonian times, with repeated sea-level rises, gradual climate warming, the onset of the Eovariscan Orogeny, and the evolution of vascular-rooted land plants all known to have occurred (e.g., Algeo and Scheckler, 1998; Sandberg et al., 2002; Averbuch et al., 2005; Joachimski et al., 2009). Because soils play a key role in improving the bioavailability of phosphorus in the modern, it is possible that the long-term rise of vascular-root systems (which would have greatly increased soil masses and erosion of them) would have been particularly important. This development would have meant that there was not only a major influx of nutrients to the marine realm during the times of enhanced terrestrial runoff associated with many of the Devonian crises, but that the phosphorus was more bioavailable than it had been previously in Earth's history (see also Algeo and Scheckler, 1998). Although that specific scenario remains speculative, it is likely that one or more of the long-term changes listed above forced the global Devonian hydrosphere towards a state whereby oxygen depletion could easily occur across 
much of the marine shelf area and/or global ocean (Carmichael et al., 2014, 2016; Song et al., 2017; White et al., 2018).

\section{Conclusions}

779

New data from several geographically widespread Late Devonian stratigraphic records have revealed that the global phosphorus cycle was repeatedly disturbed during the numerous anoxic events that took place at that time. Carbon/phosphorus molar ratios of organic matter in excess of the modern global average value of $\sim 115$ indicate that recycling of nutrients from sediments deposited in oxygen-depleted conditions maintained enhanced levels of primary productivity and water-column deoxygenation in at least some marine settings during all four of the Late Devonian crises studied here. An increase in phosphorus contents in Upper Kellwasser, Annulata, and Hangenberg strata suggests that the marine anoxia/euxinia was initiated by the increased influx of that element (and potentially other nutrients) to the marine realm during those crises. Correlations of these phosphorus peaks with evidence for enhanced weathering rates suggest that this increased nutrient input resulted from significant runoff of terrigenous material to the marine realm, although delivery of these nutrients to some shelf settings potentially required subsequent oceanic cycling and upwelling. There is no equivalent enrichment in phosphorus associated with the Lower Kellwasser Horizon, despite clear indications of increased primary productivity and oxygen depletion in the water column in the same strata. Consequently, it is suggested that the environmental perturbations associated with the Lower Kellwasser Event largely did not result from a major influx of phosphorus to the marine realm, perhaps suggesting that this lesser biotic crisis likely had a profoundly different causal mechanism to the Upper Kellwasser anoxic event and other Devonian crises. It is concluded that the development of oxygen-depleted water columns for individual locations and events was likely stimulated via a number of different mechanisms throughout the Late Devonian, highlighting that the Late Devonian marine realm was particularly susceptible to the rise of anoxic conditions during that interval. 
801 Ultimately, this tendency towards oxygen-depleted marine environments likely resulted from long-

802 term processes such as repeated sea-level rises, orogenic episodes, magmatic activity, glaciation, and

803 the evolution/geographical expansion of vascular rooted land-plants, that were taking place

804 throughout Devonian-Carboniferous times.

805

806

\section{Acknowledgements}

808

809 We greatly appreciate constructive and insightful comments that have improved this manuscript, from Paul

810 Wignall and two anonymous reviewers, laboratory assistance given by Jean-Claude Lavanchy, Olivier Reubi,

811 and we also thank Grzegorz Racki, Agnieszka Pisarzowska, David De Vleeschouwer, Anne-Christine da Silva,

812 Malcolm Wallace, Alice Shuster, and Ronnie Guthrie for scientific discussions and help collecting geological

813 samples in the field. Additional thanks go to Brahimsamba Bomou and Dominik Fleitmann for analysis of

814 phosphorus contents and carbon-isotope compositions of the Erfoud samples, respectively, and Gerta Keller and

815 the 2008 University of Princeton graduate student class to Morocco for assistance collecting the Moroccan

816 samples. We gratefully acknowledge the National Science Centre - Poland (MAESTRO grant

817 2013/08/A/ST10/00717, including M.R. and L.M.), the Natural Environment Research Council (grant number

818 NE/J01799X/1 to D.P.G.B.), the Baragwanath Research Fund (A.v.S.H.) and the University of Lausanne

819 (L.M.E.P.) for funding.

820

821

822 References

823

824 Algeo, T.J. and Ingall, E., 2007, Sedimentary Corg: P ratios, paleocean ventilation, and Phanerozoic

825 atmospheric pO2. Palaeogeography, Palaeoclimatology, Palaeoecology, 256, p. 130-155,

826 https://doi.org/10.1016/j.palaeo.2007.02.029.

827 
Algeo, T.J. and Scheckler, S.E., 1998, Terrestrial-marine teleconnections in the Devonian: links between the evolution of land plants, weathering processes, and marine anoxic events. Philosophical Transactions of the Royal Society B: Biological Sciences, 353, p. 113-130, https://doi.org/10.1098/rstb.1998.0195.

831

832 Averbuch, O., Tribovillard, N., Devleeschouwer, X., Riquier, L., Mistiaen, B. and Vliet-Lanoe, V., 2005, Mountain building-enhanced continental weathering and organic carbon burial as major causes for climatic cooling at the Frasnian-Famennian boundary (c. 376 Ma)? Terra nova, 17, p. 25-34,

836

Balter, V., Renaud, S., Girard, C. and Joachimski, M.M., 2008, Record of climate-driven morphological changes in 376 Ma Devonian fossils. Geology, 36, p. 907-910, https://doi.org/10.1130/G24989A.1.

839

Behar, F., Beaumont, V. and de B. Penteado, H.L., 2001, Rock-Eval 6 technology: performances and developments. Oil \& Gas Science and Technology, 56, p. 111-134, https://doi.org/10.2516/ogst:2001013.

843

844 Berner, R.A., Ruttenberg, K.C., Ingall, E.D. and Rao, J.L., 1993, The nature of phosphorus burial in modern marine sediments. In: Wollast, R., Mackenzie, F.T. and Chou, L. (Eds.), Interactions of C, N, P and S biogeochemical cycles and global change, p. 365-378. Springer, Berlin, Heidelberg.

847

848

Bond, D.P. and Grasby, S.E., 2017, On the causes of mass extinctions. Palaeogeography, Palaeoclimatology, Palaeoecology, 478, p. 3-29, https://doi.org/10.1016/j.palaeo.2016.11.005.

850

Bond, D.P. and Wignall, P.B., 2008, The role of sea-level change and marine anoxia in the Frasnian-Famennian (Late Devonian) mass extinction. Palaeogeography, Palaeoclimatology, Palaeoecology, 263, p. 107118, https://doi.org/10.1016/j.palaeo.2008.02.015.

854

Bond, D. and Zatoń, M., 2003, Gamma-ray spectrometry across the Upper Devonian basin succession at Kowala in the Holy Cross Mountains (Poland). Acta Geologica Polonica, 53, p. 93-99. 
Bond, D., Wignall, P.B. and Racki, G., 2004, Extent and duration of marine anoxia during the FrasnianFamennian (Late Devonian) mass extinction in Poland, Germany, Austria and France. Geological Magazine, 141, p. 173-193, https://doi.org/10.1017/S0016756804008866.

861

Buggisch, W., 1991, The global Frasnian-Famennian »Kellwasser Event«. Geologische Rundschau, 80, p. 4972, https://doi.org/10.1007/BF01828767.

864

Burnett, W.C., 1977, Geochemistry and origin of phosphorite deposits from off Peru and Chile. Geological Society of America Bulletin, 88, p. 813-823, https://doi.org/10.1130/0016-

868

Burnett, W.C., Roe, K.K. and Piper, D.Z., 1983, Upwelling and phosphorite formation in the ocean. In: Suess, E., Thiede, E., Thiede, J. (Eds.), Coastal Upwelling, Its Sediment Record, p. 377-397, Springer,

872

Caplan, M.L. and Bustin, R.M., 1999, Palaeoceanographic controls on geochemical characteristics of organicrich Exshaw mudrocks: role of enhanced primary production. Organic Geochemistry, 30, p. 161-188,

876

Caputo, M.V., 1985, Late Devonian glaciation in South America. Palaeogeography, Palaeoclimatology, Palaeoecology, 51, p. 291-317, https://doi.org/10.1016/0031-0182(85)90090-2.

879

880

Carmichael, S.K., Waters, J.A., Suttner, T.J., Kido, E. and DeReuil, A.A., 2014, A new model for the Kellwasser Anoxia Events (Late Devonian): Shallow water anoxia in an open oceanic setting in the

882

883 Central Asian Orogenic Belt. Palaeogeography, Palaeoclimatology, Palaeoecology, 399, p. 394-403,

884

885

Carmichael, S.K., Waters, J.A., Batchelor, C.J., Coleman, D.M., Suttner, T.J., Kido, E., Moore, L.M. and 886 Chadimová, L., 2016, Climate instability and tipping points in the Late Devonian: detection of the 
889

890 Casier, J.G. and Lethiers, F., 1998, Ostracods Late Devonian mass extinction: the Schmidt quarry parastratotype (Kellerwald, Germany). Comptes Rendus de l'Académie des Sciences - Series IIA - Earth and

893

894

Casier, J.G., Lethiers, F. and Baudin, F., 1999, Ostracods, organic matter and anoxic events associated with the Frasnian/Famennian boundary in the Schmidt quarry (Germany). Geobios, 32, p. 869-881,

897

898

Chen, D., Qing, H. and Li, R., 2005, The Late Devonian Frasnian-Famennian (F/F) biotic crisis: insights from $\delta 13 \mathrm{Ccarb}, \delta 13 \mathrm{Corg}$ and $87 \mathrm{Sr} / 86 \mathrm{Sr}$ isotopic systematics. Earth and Planetary Science Letters, 235, p.

901

902

Copper, P., 1986, Frasnian/Famennian mass extinction and cold-water oceans. Geology, 14, p. 835-839, https://doi.org/10.1130/0091-7613(1986)14<835:FMEACO>2.0.CO;2.

904

905

Copper, P., 1998. Evaluating the Frasnian-Famennian mass extinction: Comparing brachiopod faunas. Acta Palaeontologica Polonica, 43, p. 137-154.

907

908

Dale, A.W., Boyle, R.A., Lenton, T.M., Ingall, E.D. and Wallmann, K., 2016, A model for microbial phosphorus cycling in bioturbated marine sediments: significance for phosphorus burial in the early Paleozoic. Geochimica et Cosmochimica Acta, 189, p. 251-268,

912

913 De Vleeschouwer, D., Rakociński, M., Racki, G., Bond, D.P., Sobień, K. and Claeys, P., 2013, The astronomical rhythm of Late-Devonian climate change (Kowala section, Holy Cross Mountains, Poland). Earth and Planetary Science Letters, 365, p. 25-37, https://doi.org/10.1016/j.epsl.2013.01.016. 
917 De Vleeschouwer, D., Da Silva, A.C., Sinnesael, M., Chen, D., Day, J.E., Whalen, M.T., Guo, Z. and Claeys,

918 P., 2017, Timing and pacing of the Late Devonian mass extinction event regulated by eccentricity and

919 obliquity. Nature communications, 8, https://doi.org/10.1038/s41467-017-02407-1.

920

921 Delaney, M.L., 1998, Phosphorus accumulation in marine sediments and the oceanic phosphorus cycle. Global Biogeochemical Cycles, 12, p. 563-572, https://doi.org/10.1029/98GB02263.

923

924 Derkowski, A. and Marynowski, L., 2018, Binding of heavy metals by oxidised kerogen in (palaeo) weathered black shales. Chemical Geology, 493, p. 441-450, https://doi.org/10.1016/j.chemgeo.2018.06.025.

926

927

928

Devleeschouwer, X., Herbosch, A. and Préat, A., 2002, Microfacies, sequence stratigraphy and clay mineralogy of a condensed deep-water section around the Frasnian/Famennian boundary (Steinbruch Schmidt,

930 Germany). Palaeogeography, Palaeoclimatology, Palaeoecology, 181, p. 171-193,

931

932

Eaton, A.D., Clesceri, L.S., Greenberg, A.E., 1995, Standard Methods for the Examination of Water and Waste Water. American Public Health Association, American Water Works Association, Water Pollution Control Federation and Water Environment Federation, 2, p. 4113-4114. American Public Health Association.

936

Fantasia, A., Föllmi, K.B., Adatte, T., Spangenberg, J.E. and Montero-Serrano, J.C., 2018, The Early Toarcian oceanic anoxic event: Paleoenvironmental and paleoclimatic change across the Alpine Tethys (Switzerland). Global and Planetary Change, 162, p. 53-68, https://doi.org/10.1016/j.gloplacha.2018.01.008.

Filippelli, G.M., 2008, The global phosphorus cycle: past, present, and future. Elements, 4, p. 89-95, https://doi.org/10.2113/GSELEMENTS.4.2.89. Neogene. Paleoceanography and Paleoclimatology, 9, p. 643-652, https://doi.org/10.1029/94PA01453. 
948 Föllmi, K.B., 1995, 160 m.y. record of marine sedimentary phosphorus burial: Coupling of climate and continental weathering under greenhouse and icehouse conditions. Geology, 23, p. 503-506, https://doi.org/10.1130/0091-7613(1995)023<0503:MYROMS>2.3.CO;2.

951

Föllmi, K.B., 1996, The phosphorus cycle, phosphogenesis and marine phosphate-rich deposits. Earth-Science Reviews, 40, p. 55-124, https://doi.org/10.1016/0012-8252(95)00049-6.

954

955

Froelich, P.N., Bender, M.L., Luedtke, N.A., Heath, G.R. and DeVries, T., 1982, The marine phosphorus cycle. American Journal of Science, 282, p. 474-511, https://doi.org/10.2475/ajs.282.4.474.

957

958

Fung, I.Y., Meyn, S.K., Tegen, I., Doney, S.C., John, J.G. and Bishop, J.K., 2000, Iron supply and demand in

959

960 the upper ocean. Global Biogeochemical Cycles, 14, p. 281-295,

961

962

George, A.D., 1999, Deep-water stromatolites, Canning Basin, northwestern Australia. Palaios, 14, p. 493-505, https://doi.org/10.2307/3515399.

964

965

George, A.D., Playford, P.E., Powell, C.M. and Tornatora, P.M., 1997, Lithofacies and sequence development 966 on an Upper Devonian mixed carbonate-siliciclastic fore-reef slope, Canning Basin, Western Australia. Sedimentology, 44, p. 843-867, https://doi.org/10.1046/j.1365-3091.1997.d01-52.x.

968

969

Hillbun, K., Playton, T.E., Tohver, E., Ratcliffe, K., Trinajstic, K., Roelofs, B., Caulfield-Kerney, S., Wray, D., Haines, P., Hocking, R. and Katz, D., 2015, Upper Kellwasser carbon isotope excursion pre-dates the F-F boundary in the Upper Devonian Lennard Shelf carbonate system, Canning Basin, Western Australia. Palaeogeography, Palaeoclimatology, Palaeoecology, 438, p. 180-190, https://doi.org/10.1016/j.palaeo.2015.07.035.

974 elemental composition of some marine phytoplankton 1. Journal of phycology, 39, p. 1145-1159. 
978 Huang, C., Joachimski, M.M. and Gong, Y., 2018, Did climate changes trigger the Late Devonian Kellwasser Crisis? Evidence from a high-resolution conodont $8180 \mathrm{OPO} 4$ record from South China. Earth and Planetary Science Letters, 495, p. 174-184, https://doi.org/10.1016/j.epsl.2018.05.016.

981

982

Hutchins, D.A., Hare, C.E., Weaver, R.S., Zhang, Y., Firme, G.F., DiTullio, G.R., Alm, M.B., Riseman, S.F., Maucher, J.M., Geesey, M.E., Trick, C.G., Smith, G.J., Rue, E.L., Conn, J. and Bruland, K.W., 2002, Phytoplankton iron limitation in the Humboldt Current and Peru Upwelling. Limnology and Oceanography, 47, p. 997-1011, https://doi.org/10.4319/lo.2002.47.4.0997.

986

Jenkyns, H.C., 2010, Geochemistry of Oceanic Anoxic Events. Geochemistry Geophysics Geosystems, 11, Q03004, https://doi.org/10.1029/2009GC002788.

989

990

Joachimski, M.M. and Buggisch, W., 1993, Anoxic events in the late Frasnian-Causes of the FrasnianFamennian faunal crisis? Geology, 21, p. 675-678, https://doi.org/10.1130/0091-

993

Joachimski, M.M. and Buggisch, W., 2002, Conodont apatite $\delta 180$ signatures indicate climatic cooling as a trigger of the Late Devonian mass extinction. Geology, 30, p. 711-714, https://doi.org/10.1130/0091-

997

Joachimski, M.M., Ostertag-Henning, C., Pancost, R.D., Strauss, H., Freeman, K.H., Littke, R., Damste, J.S.S. and Racki, G., 2001, Water column anoxia, enhanced productivity and concomitant changes in $\delta 13 \mathrm{C}$ 7613(2002)030<0711:CAOSIC>2.0.CO;2.

1003 isotope geochemistry of the Frasnian-Famennian transition. Palaeogeography, Palaeoclimatology, Palaeoecology, 181, p. 91-109, https://doi.org/10.1016/S0031-0182(01)00474-6. 
1008 Joachimski, M.M., Breisig, S., Buggisch, W., Talent, J.A., Mawson, R., Gereke, M., Morrow, J.R., Day, J. and 1009 Weddige, K., 2009, Devonian climate and reef evolution: insights from oxygen isotopes in

1010 apatite. Earth and Planetary Science Letters, 284, p. 599-609,

1011 https://doi.org/10.1016/j.epsl.2009.05.028.

1012

1013 Kaiho, K., Yatsu, S., Oba, M., Gorjan, P., Casier, J.G. and Ikeda, M., 2013, A forest fire and soil erosion event during the Late Devonian mass extinction. Palaeogeography, Palaeoclimatology, Palaeoecology, 392, p. 272-280, https://doi.org/10.1016/j.palaeo.2013.09.008.

1016

1017 Kaiser, S.I., Steuber, T., Becker, R.T. and Joachimski, M.M., 2006, Geochemical evidence for major environmental change at the Devonian-Carboniferous boundary in the Carnic Alps and the Rhenish Massif. Palaeogeography, Palaeoclimatology, Palaeoecology, 240, p. 146-160,

1021

1022

Kaiser, S.I., Aretz, M. and Becker, R.T., 2016, The global Hangenberg Crisis (Devonian-Carboniferous transition): review of a first-order mass extinction. Geological Society, London, Special Publications, 423, p. 387-437, https://doi.org/10.1144/SP423.9.

1025

1026

Klapper, G., Feist, R., Becker, R.T. and House, M.R., 1993, Definition of the Frasnian/Famennian Stage boundary. Episodes, 16, p. 433-441.

Kolowith, L.C. and Berner, R.A., 2002, Weathering of phosphorus in black shales. Global Biogeochemical Cycles, 16, https://doi.org/10.1029/2001GB001887.

Korn, D., 2010, The mid-Famennian ammonoid succession in the Rhenish Mountains: the" annulata Event" reconsidered. Geological Quarterly, 48, p. 245-252. 
Kraal, P., Slomp, C.P., Forster, A. and Kuypers, M.M., 2010, Phosphorus cycling from the margin to abyssal depths in the proto-Atlantic during oceanic anoxic event 2. Palaeogeography, Palaeoclimatology, Palaeoecology, 295, p. 42-54, https://doi.org/10.1016/j.palaeo.2010.05.014.

1038

Le Houedec, S., Girard, C. and Balter, V., 2013, Conodont $\mathrm{Sr} / \mathrm{Ca}$ and $\delta 18 \mathrm{O}$ record seawater changes at the Frasnian-Famennian boundary. Palaeogeography, Palaeoclimatology, Palaeoecology, 376, p. 114-121, https://doi.org/10.1016/j.palaeo.2013.02.025.

1042

1043 Martinez, A.M., Boyer, D.L., Droser, M.L., Barrie, C. and Love, G.D., 2019, A stable and productive marine microbial community was sustained through the end-Devonian Hangenberg Crisis within the Cleveland Shale of the Appalachian Basin, United States. Geobiology, 17, p. 27-42, https://doi.org/10.1111/gbi.12314.

Martiny, A.C., Pham, C.T., Primeau, F.W., Vrugt, J.A., Moore, J.K., Levin, S.A. and Lomas, M.W., 2013, Strong latitudinal patterns in the elemental ratios of marine plankton and organic matter. Nature Geoscience, 6, p. 279-283, https://doi.org/10.1038/ngeo1757.

1051

1052

Marynowski, L., Rakociński, M., Borcuch, E., Kremer, B., Schubert, B.A. and Jahren, A.H., 2011, Molecular and petrographic indicators of redox conditions and bacterial communities after the F/F mass extinction

Marynowski, L., Zatoń, M., Rakociński, M., Filipiak, P., Kurkiewicz, S. and Pearce, T.J., 2012, Deciphering the (Kowala, Holy Cross Mountains, Poland). Palaeogeography, Palaeoclimatology, Palaeoecology, 306, p. 1-14, https://doi.org/10.1016/j.palaeo.2011.03.018.

Marynowski, L., Pisarzowska, A., Derkowski, A., Rakociński, M., Szaniawski, R., Środoń, J. and Cohen, A.S., upper Famennian Hangenberg Black Shale depositional environments based on multi-proxy record. Palaeogeography, Palaeoclimatology, Palaeoecology, 346, p. 66-86, https://doi.org/10.1016/j.palaeo.2012.05.020. 2017, Influence of palaeoweathering on trace metal concentrations and environmental proxies in black 
McGhee, G.R., 1996, The late Devonian mass extinction: the Frasnian/Famennian crisis. Columbia University Press, New York.

1069

Meischner, D., 1971, Clastic sedimentation in the Variscan geosyncline east of the River Rhine. In: Sedimentology of Parts of Central Europe, p. 9-43. International Sedimentological Congress, Guidebook VIII.

1073

Mort, H.P., Adatte, T., Föllmi, K.B., Keller, G., Steinmann, P., Matera, V., Berner, Z. and Stüben, D., 2007, Phosphorus and the roles of productivity and nutrient recycling during oceanic anoxic event 2. Geology, 35, p. 483-486, https://doi.org/10.1130/G23475A.1.

1077

1078

1079

1080

1081

Murphy, A.E., Sageman, B.B. and Hollander, D.J., 2000, Eutrophication by decoupling of the marine biogeochemical cycles of C, N, and P: A mechanism for the Late Devonian mass

1082

1083

Myrow, P.M., Ramezani, J., Hanson, A.E., Bowring, S.A., Racki, G. and Rakociński, M., 2014, High-precision $\mathrm{U}-\mathrm{Pb}$ age and duration of the latest Devonian (Famennian) Hangenberg event, and its

1086

Paschall, O., Carmichael, S.K., Königshof, P., Waters, J.A., Ta, P.H., Komatsu, T. and Dombrowski, A., 2019, implications. Terra Nova, 26, p. 222-229, https://doi.org/10.1111/ter.12090.

Paytan, A. and McLaughlin, K., 2007, The oceanic phosphorus cycle. Chemical reviews, 107, p. 563-576, https://doi.org/10.1021/cr0503613. 
Percival, L.M.E., Davies, J.H.F.L., Schaltegger, U., De Vleeschouwer, D., Da Silva, A.-C. and Föllmi, K.B., 2018, Precisely dating the Frasnian-Famennian boundary: implications for the cause of the Late

Percival, L.M.E., Selby, D., Bond, D.P.G., Rakociński, M., Racki, G., Marynowski, L., Adatte, T., Devonian mass extinction. Scientific Reports, 8, https://doi.org/10.1038/s41598-018-27847-7. Spangenberg, J.E. and Föllmi, K.B., 2019, Osmium-isotope evidence for pulses of extreme continental weathering associated with multiple Late Devonian climate perturbations. Palaeogeography,

Peters, K.E., 1986, Guidelines for evaluating petroleum source rock using programmed pyrolysis. American Association of Petroleum Geologists bulletin, 70, p. 318-329.

Playford, P.E., 1980, Devonian" Great Barrier Reef" of Canning Basin. Western Australia: American Association of Petroleum Geologists Bulletin, 64, p. 814-840.

Playton, T.E., Hocking, R.M., Tohver, E., Hillburn, K., Haines, P.W., Trinajstic, K., Roelofs, B., Katz, D.A., Kirschvink, J.L., Grice, K. and Montgomery, P., 2016, Integrated stratigraphic correlation of Upper Devonian platform-to-basin carbonate sequences, Lennard Shelf, Canning Basin, Western Australia:

Pujol, F., Berner, Z. and Stüben, D., 2006, Palaeoenvironmental changes at the Frasnian/Famennian boundary in key European sections: Chemostratigraphic constraints. Palaeogeography, Palaeoclimatology, Palaeoecology, 240, p. 120-145, https://doi.org/10.1016/j.palaeo.2006.03.055. events in the Late Famennian of the Holy Cross Mountains (Southern Poland): geochemical and palaeontological record. Palaeogeography, Palaeoclimatology, Palaeoecology, 297, p. 549-575, https://doi.org/10.1016/j.palaeo.2010.08.028. 
1125 Racki, G., Racka, M., Matyja, H. and Devleeschouwer, X., 2002, The Frasnian/Famennian boundary interval in the South Polish-Moravian shelf basins: integrated event-stratigraphical approach. Palaeogeography,

Racki, G., 2005, Toward understanding Late Devonian global events: few answers, many questions. In Developments in Palaeontology and Stratigraphy, 20 (p. 5-36) Elsevier.

Raup, D.M. and Sepkoski, J.J., 1982, Mass Extinction in the Marine Fossil Record. Science, 215, p. 1501-1503, d https://doi.org/10.1126/science.215.4539.1501.

Redfield, A.C., 1958, The biological control of chemical factors in the environment. American scientist, 46, p. 230A, 205-221.

Rimmer, S.M., Hawkins, S.J., Scott, A.C. and Cressler, W.L., 2015, The rise of fire: fossil charcoal in late Devonian marine shales as an indicator of expanding terrestrial ecosystems, fire, and atmospheric change. American Journal of Science, 315, p. 713-733, https://doi.org/10.2475/08.2015.01. Kellwasser horizons of the Harz Mountains (Germany): two oxygen-deficient periods resulting from different mechanisms. Chemical Geology, 233, p. 137-155,

Sageman, B.B., Murphy, A.E., Werne, J.P., Ver Straeten, C.A., Hollander, D.J. and Lyons, T.W., 2003, A tale https://doi.org/10.1016/j.chemgeo.2006.02.021. of shales: the relative roles of production, decomposition, and dilution in the accumulation of organicmass extinctions. Geological Society of America Special Papers, 356, p. 473-488. 
1155 Schindler, E., 1990, Die Kellwasser-Krise (hohe Frasne-Stufe, Ober Devon). Göttinger Arbeiten zur Geologie und Paläontologie, 46, p. 1-115.

1158 Schenau, S.J. and De Lange, G.J., 2000, A novel chemical method to quantify fish debris in marine sediments. Limnology and Oceanography, 45, p. 963-971, https://doi.org/10.4319/lo.2000.45.4.0963.

1160

Song, H., Song, H., Algeo, T.J., Tong, J., Romaniello, S.J., Zhu, Y., Chu, D., Gong, Y. and Anbar, A.D., 2017, Uranium and carbon isotopes document global-ocean redox-productivity relationships linked to cooling during the Frasnian-Famennian mass extinction. Geology, 45, p. 887-890, https://doi.org/10.1130/G39393.1.

1165

Stephens, N.P. and Sumner, D.Y., 2003, Late Devonian carbon isotope stratigraphy and sea level fluctuations, Canning Basin, Western Australia. Palaeogeography, Palaeoclimatology, Palaeoecology, 191, p. 203219, https://doi.org/10.1016/S0031-0182(02)00714-9.

1169

Streel, M., Caputo, M.V., Loboziak, S. and Melo, J.H.G., 2000, Late Frasnian-Famennian climates based on palynomorph analyses and the question of the Late Devonian glaciations. Earth-Science Reviews, 52, p. 121-173, https://doi.org/10.1016/S0012-8252(00)00026-X.

1173

Szulczewski, M., 1996, Devonian succession in the Kowala quarry and railroad cut. In Sixth European Conodont Symposium (ECOS VI), Excursion Guide (p. 27-30).

1176

Taylor, S.R. and McLennan, S.M., 1995, The geochemical evolution of the continental crust. Reviews of Geophysics, 33, p. 241-265, https://doi.org/10.1029/95RG00262.

1179

1180 Tulipani, S., Grice, K., Greenwood, P.F., Haines, P.W., Sauer, P.E., Schimmelmann, A., Summons, R.E., Foster, C.B., Böttcher, M.E., Playton, T. and Schwark, L., 2015, Changes of palaeoenvironmental conditions recorded in Late Devonian reef systems from the Canning Basin, Western Australia: a 

https://doi.org/10.1016/j.gr.2014.10.003.

1185

1186 Turgeon, S.C., Creaser, R.A. and Algeo, T.J., 2007, Re-Os depositional ages and seawater Os estimates for the Frasnian-Famennian boundary: implications for weathering rates, land plant evolution, and extinction mechanisms. Earth and Planetary Science Letters, 261, p. 649-661,

Van Cappellen, P. and Ingall, E.D., 1994, Benthic phosphorus regeneration, net primary production, and ocean anoxia: a model of the coupled marine biogeochemical cycles of carbon and phosphorus. Paleoceanography, 9, p. 677-692, https://doi.org/10.1029/94PA01455.

Walliser, O.H., 1984, Geologic processes and global events. Terra cognita, 4, p. 17-20.

Walliser, O.H., 1996, Global events in the Devonian and Carboniferous. In Global events and event stratigraphy in the Phanerozoic (p. 225-250), Springer, Berlin, Heidelberg.

1199

Weiner, T., Kaldova, J., Kumpan, T., Schindler, E. and Šimíček, D., 2017, An Integrated Stratigraphy of the Frasnian-Famennian Boundary Interval (Late Devonian) in the Moravian Karst (Czech Republic) and Kellerwald (Germany). Bulletin of Geosciences, 92, p. 257-281,

Wendt, J. and Belka, Z., 1991, Age and depositional environment of Upper Devonian (early Frasnian to early Famennian) black shales and limestones (Kellwasser facies) in the eastern Anti-Atlas, Morocco. Facies, 25, p. 51-89, https://doi.org/10.1007/BF02536755. changes in the redox conditions of the western Tethys Ocean during the early Aptian oceanic anoxic event. Geochimica et Cosmochimica Acta, 121, p. 467-486, https://doi.org/10.1016/j.gca.2013.07.023. 
1213 Whalen, M.T., Śliwiński, M.G., Payne, J.H., Day, J.E.J., Chen, D. and Da Silva, A.C., 2015, Chemostratigraphy

1214 and magnetic susceptibility of the Late Devonian Frasnian-Famennian transition in western Canada

1215 and southern China: implications for carbon and nutrient cycling and mass extinction. Geological

1216 Society, London, Special Publications, 414, p. 37-72, https://doi.org/10.1144/SP414.8.

1217

1218 White, D.A., Elrick, M., Romaniello, S. and Zhang, F., 2018, Global seawater redox trends during the Late

1219 Devonian mass extinction detected using U isotopes of marine limestones. Earth and Planetary Science Letters, 503, p. 68-77, https://doi.org/10.1016/j.epsl.2018.09.020.

1221

1222

Wilder, H., 1994, Death of Devonian reefs - implications and further investigations. Courier Forschungsinstitut Senckenberg, 172, p. 241-247.

Yudina, A.B., Racki, G., Savage, N.M., Racka, M. and Małkowski, K., 2002, The Frasnian-Famennian events in a deep-shelf succession, Subpolar Urals: biotic, depositional, and geochemical records. Acta Palaeontologica Polonica, 47, p. 355-372.

\section{Figure Captions}

Figure 1: Palaeogeographic map of the Late Devonian world, adapted from Percival et al., 2018. The locations of sedimentary sequences presented are as follows (white circles mark sites where the $\mathrm{P}_{\text {tot }}$ data are new for this study; the black circle indicates an area where $\mathrm{P}_{\text {tot }}$ data have been

Figure 2: Previously published geochemical data plots of $\delta^{13} \mathrm{C}$, TOC, $\mathrm{P}_{\text {tot }}, \mathrm{TOC} / \mathrm{P}_{\text {tot, }}$ and Os-isotope trends for the West Valley Core (Murphy et al., 2000; Sageman et al., 2003; Turgeon et al., 
2007), with lithological and biostratigraphic information adapted from the same sources. All vertical scales are in meters. Fm., ling., and triang. indicate the Famennian Stage and linguiformis and triangularis conodont Zones, respectively. The TOC/ $\mathrm{P}_{\text {org }}$ modern global

1247 Figure 3: Geochemical data plots of $\delta^{13} \mathrm{C}$ and $\mathrm{P}_{\text {tot }}$, for all Kellwasser Horizons where new $\mathrm{P}$ data is presented for this study. $\mathrm{P}_{\text {tot }}$ concentrations normalized to $\mathrm{Al}$ contents $\left(\mathrm{P}_{\text {tot }} / \mathrm{Al}\right)$, together with TOC and TOC/ $\mathrm{P}_{\text {tot }}$ measurements, are also presented from sedimentary records of the Kellwasser horizons at (A) Steinbruch Schmidt, Germany, (B) Kowala, Poland (C) Coumiac, France, and (D) Erfoud, Morocco ( $\mathrm{P}_{\text {tot }} / \mathrm{Al}$ only). All vertical scales are in meters; the stratigraphic positions of the Lower (LKW) and Upper (UKW) Kellwasser horizons are indicated by the grey bars. Zone refers to conodont biostratigraphic Zones. Fm., ling., and triang. indicate the Famennian Stage and linguiformis and triangularis conodont Zones, respectively. The TOC $/ \mathrm{P}_{\text {org }}$ modern global average ratio is marked on all TOC/ $\mathrm{P}_{\text {tot }}$ plots at 115 (Dale et al., 2016), and the upper crustal average P/Al ratio ( 0.01; Taylor and McLennan, 1995) is indicated on all $\mathrm{P}_{\text {tot }} / \mathrm{Al}$ plots. All $\mathrm{P}_{\text {tot }}, \mathrm{P}_{\text {tot }} / \mathrm{Al}$, and TOC/ $\mathrm{P}_{\text {tot }}$ data are from this study. TOC data from Kowala are from Percival et al. (2019). TOC data from Steinbruch Schmidt and Coumiac, and $\delta^{13} \mathrm{C}$ data from Erfoud, are from this study. Previously published carbon-isotope data are sourced as follows: Steinbruch Schmidt and Coumiac from Joachimski and Buggisch (1993); Kowala from Percival et al. (2019); South Oscar Range from Playton et al. (2016); Dingo Gap from Stephens and Sumner (2003). Biostratigraphic data are sourced as follows: Steinbruch Schmidt from Schindler (1990); Coumiac from Bond et al. (2004); Erfoud from this study; South Oscar Range from Playton et al. (2016). Lithological data are sourced as follows: Steinbruch Schmidt from Schindler (1990); Kowala from Percival et al. (2019); Coumiac from Bond et al. (2004); all other sites from this study. Osmium-isotope data from Kowala are from Percival et al. (2019); Note the variable scales for TOC, and the colour distinction between dark green for representing $\delta^{13} \mathrm{C}_{\text {org }}$ and light green for $\delta^{13} \mathrm{C}_{\text {org }}$. 
1272 Figure 4: Geochemical data plots for TOC, $\mathrm{P}_{\text {tot }}, \mathrm{P}_{\text {tot }} / \mathrm{Al}$ and TOC/ $\mathrm{P}_{\text {tot }}$ measurements from sedimentary records of the (A) Hangenberg and (B) Annulata horizons at Kowala, Poland. All vertical scales are in meters; the stratigraphic positions of the Annulata and Hangenberg horizons are indicated by the grey bars. Zone refers to conodont biostratigraphic Zones. To. and sul. indicate the Tournasian Stage and sulcata conodont Zone, respectively. The TOC $/ \mathrm{P}_{\text {org }}$ modern global average ratio is marked on all TOC/ $\mathrm{P}_{\text {tot }}$ plots at 115 (Dale et al., 2016), and the upper crustal average P/Al ratio ( 0.01; Taylor and McLennan, 1995) is indicated on all $\mathrm{P}_{\text {tot }} / \mathrm{Al}$ plots. All data are from this study. Lithological data are sourced as follows: for the Hangenberg Horizon from Myrow et al. (2014); for the Annulata Horizon from this study. Biostratigraphic data are sourced as follows: for the Hangenberg Horizon from Myrow et al. (2014); for the Annulata Horizon from Racka et al. (2010).

1283

1284

Figure 5: Geochemical evidence for trends in global continental weathering, and local detrital influx

1290

Figure 6: Geochemical evidence for trends in global continental weathering, and local detrital influx to the settings during the (A) Hangenberg and (B) Annulata events recorded at Kowala. All vertical scales are in meters. Biostratigraphic, lithological, and $\mathrm{P}_{\text {tot }} / \mathrm{Al}$ information as for Figure 4. Osmium-isotope data are from Percival et al. (2019); Si/Al and Ti/Al data are from this study. The upper crustal average $\mathrm{Si} / \mathrm{Al}, \mathrm{Ti} / \mathrm{Al}$, and $\mathrm{P} / \mathrm{Al}$ ratios (Taylor and McLennan, 1995) are indicated. 
1297

1298 